\title{
KEKUATAN EMAIL SEBAGAI ALAT BUKTI DALAM PROSES PERSIDANGAN PERKARA PERDATA
}

\author{
Cokorda Agung Cahaya Darmadi, I Made Minggu Widyantara, Ni Made Sukaryati Karma \\ Fakultas Hukum, Universitas Warmadewa, Denpasar-Bali, Indonesia \\ cokcahaya98@gmail.com, mademinggu21@gmail.com, madesukaryatikarma@gmail.com
}

\begin{abstract}
Abstrak
Perkembangan teknologi dan telekomunikasi yang semakin pesat memudahkan seseorang mengirim surat melalui e-mail sebab penggunaan email tersebut dianggap murah dan cepat. Selain itu data yang kita kirim via email akan tersimpan, sehingga bila suatu waktu ada masalah terkait surat tersebut maka mudah menemukan bukti fisik surat tersebut di email. Dari fenomena ini, maka penelitian ini dilakukan dengan tujuan untuk mengkaji bagaimana pembuktian penggunaan email berdasarkan Undang-undang ITE dan menelaah kekuatan email dalam proses persidangan apabila dikaitkan dengan pasal 1866 KUHPerdata. Penelitian ini menggunakan tipe penelitian hukum normatif dengan menerapkan pendekatan Perundangundangan dan pendekatan kasus. Bahan hukum yang digunakan yaitu primer, sekunder dan tersier yang diperoleh melalui studi kepustakaan. Setelah data terkumpul maka data tersebut diolah secara analisis kualitatif deskriptif. Hasil penelitian menunjukkan bahwa pembuktian email sebagai alat bukti dalam persidangan perkara perdata dapat digunakan dalam persidangan mengenai aspek hukum penerapan email dalam menegakkan hukum dengan adanya perkembangan teknologi sekarang ini melalui media komunikasi yang dikenal dengan internet telah mengubah cara berpikir dan bertindak yang kemudian berdampak pada hukum. Kekuatan alat bukti e-mail sebagai proses pembuktian dalam persidangan bila dikaitkan dengan Pasal 164 HIR mengenai alat bukti yang sah.
\end{abstract}

Kata Kunci: Alat bukti, Kekuatan Email, Persidangan, Perkara Perdata

\begin{abstract}
The rapid development of technology and telecommunications makes it easier for someone to send a letter via email because the use of e-mail is considered cheap and fast. In addition, the data that we send via email will be stored, so that if at any time there is a problem related to the letter, it is easy to find physical evidence of the letter in the email. From this phenomenon, this research was conducted with the aim of examining how to prove the use of email based on the ITE Law and examine the strength of email in the trial process when it is associated with article 1866 of the Civil Code. This study uses a normative legal research type by applying the legislation approach and the case approach. The legal materials used are primary, secondary and tertiary obtained through literature study. After the data is collected, the data is processed by descriptive qualitative analysis. The results of the study show that e-mail verification as evidence in civil case trials can be used in trials regarding the legal aspects of e-mail application in enforcing the law. With the development of today's technology through communication media known as the internet, it has changed the way of thinking and acting which then has an impact on the law. The strength of e-mail evidence as a process of proof in court when it is associated with Article 164 HIR regarding valid evidence.
\end{abstract}

Keywords: Evidence, Email Strength, Trial, Civil Case

\section{PENDAHULUAN}

Hukum Acara Perdata digunakan oleh sistem peradilan untuk menyelesaikan masalah yang timbul antara satu pihak dengan pihak lain (Tutik, 2006). Hukum acara perdata adalah seperangkat aturan yang berkaitan dengan hubungan hukum dengan badan hukum, antara badan hukum dan subjek, dan hubungan hukum yang tidak berada dalam ruang lingkup hukum peraturan hukum pidana (Prodjodikoro, 2003). Ini tidak berarti kemungkinan mencapai aturan pidana dan administrasi yang tidak melibatkan instansi pemerintah dalam pelaksanaan kekuasaan dan tugas.

Hukum acara mengkaji serangkaian aturan tentang hubungan hukum antara orang perseorangan atau badan hukum tentang hak dan kewajiban orang lainnya dengan suatu benda 
(Hamzah, 2014). Hubungan dengan hukum tersebut bukanlah hukum pidana dan tidak dibarengi dengan kemungkinan hukum pidana. Apa itu pemerintahan hukum administrasi dan tidak ada hubungannya dengan tubuh Pemerintah memenuhi wewenang dan kewajibannya (Subekti, 1989). Sementara itu. Hukum acara perdata memiliki keterbatasan, yaitu mengatur bagaimana menggunakan mediasi hakim untuk mengetahui keasaman terhadap kukum perdata yang substansial. Dengan kata lain, hukum acara perdata adalah hukum yang menggemukkan gimana pelaksanaan acara itu dibandingkan dengan badan hukum perdata (Mertokusumo, 1998). Lebih mendalamkan lagi, dapat dibicarakan bahwa hukum acara perdata menghaturkan tentang cara pengajuan gugatan, peninjauan kembali dan putusan, serta pelaksanaan putusan tersebut (Zazili, 2012).

Perkara perdata adalah masalah kontroversial hak, kewajiban atau perintah dan perintah antara orang perseorangan (subjek hukum) dan orang lain (subyek hukum) di bidang perdata. Dalam praktik peradilan, hakim mungkin memiliki sikap yang berbeda ketika melihat alat bukti edokument, yaitu sebagian orang beranggapan bukti itu iyalah edocument merupakan alat bukti yang efektif selain alat bukti konvensional (Fathurrahman, 2018). Berkas elektronik merupakan alat pembuktian tambahan dan harus didukung alat bukti lain untuk dipertimbangkan oleh hakim. Hukum acara perdata dibatasi alat pembuktian yang dapat dipergunakan untuk membuktikan di persidangan suatu perkara, dan memiliki normativitas yang terbatas.

UU ITE adalah payung aturan bagi segala kegiatan dan transaksi pada semua internet dan media elektronik, misalnya, blog dapat mempertahankan terhadap serangan seperti pencurian digital, perubahan penampilan, dll. Namun, di antara manfaat yang terkandung dalam hukum, ada sesuatu yang mengkhawatirkan, tidak hanya untuk wartawan, tetapi juga untuk blogger, itu adalah Pasal 27 (3). Dengan mudah membuat semua dokumen atau karya yang dipublikasikan di situs web dan blog menjadi subjek litigasi. Sebagai contoh, sebuah artikel tentang produk yang buruk atau layanan dapat menyebabkan penulis untuk menuntut blogger untuk pencemaran nama baik. Mengkritik pejabat karena kinerja yang buruk dapat dianggap sebagai penghinaan (Anggara, 2010).

Pada era layanan digital seperti sekarang ini, perkembangan internet sangat cepat. Selain itu, masih terdapat pelayanan dengan mendukung suatu aktivitas atau kegiatan lainnya, manusia melalui sosial internet. Dengan Salah satu channel yang terkenal sejak ditemukannya internet merupakan surat elektronik (email). Email merupakan suatu cara untuk mengirimkan berkas dalam format digital dengan melalui Sosial media (Yuliana, 2000). Email kini semakin menarik dengan teknologi email HTML, sehingga email tidak hanya ditulis, tetapi anda juga bisa menyisipkan gambar dan file lainnya. Oleh karena itu perkembangan email yang pada awalnya dirancang saling berkomunikasi sudah menjadi hal yang lumrah karena mendapatkan sesuatu yang dapat dipergunakan sebagai suatu alat informasi dan bertransaksi di sosial media. Email juga berfungsi sebagai identitas pribadi, karena di era layanan digital yang serba cepat saat ini, email sering digunakan sebagai salah satu cara untuk mengkonfirmasi identitas (Saleh, 2007).

Keabsahan Tampaknya ada masalah dalam mengakui data elektro menjadi indera berbagai suatu alat pembuktian di pengadilan. Dalam praktik peradilan Indonesia, tidak lazim memakai data elektro menjadi indera yang sah. Namun, di beberapa negara atau wilayah, hakim mempertimbangkan data elektronik berupa email ketika memutuskan suatu perkara (perdata atau pidana), sehingga tidak perlu menunggu terlalu kelamaan. Email dapat diakui oleh hukum sebagai bukti. Dengan perkembangan teknologi, keberadaan dokumen ini telah menjadi hasil dari praktik komersial. Cakupannya sangat luas, seperti menyetujui, merekam, dan mengumpulkan aneka macam bentuk data, termasuk Undang-undang, pendapat, output penelitian yg didapatkan selama transaksi, atau hasil penelitian yang dihasilkan melalui penggunaan komputer untuk bertukar informasi. Semua bukti diakui secara aturan selesainya mendengar pendapat para ahli (informasi). Apabila sebelumnya sudah terdapat tunjangan profesi metode bisnis, arsip tersebut juga dapat diidentifikasi tanpa informasi apa pun. Dengan semua pembukuan yang telah diakui secara hukum sehabis mendengar dengan para ahli (informasi). Namun, pengadilan ini sendiri tidak bisa menerima begitu saja bukti elektronik berupa email sebagai alat bukti valid untuk pengadilan. Apa yang anda lakukan di Indonesia melalui media internet tidak boleh melanggar hukum yang memadai (Iman Sjahputra 2002). Pada 2010, diperkirakan akan mencapai satu juta pengguna email, dengan mempertimbangkan lebih banyak jejaring sosial umum, seperti Instagram, Facebook dan lainnya terhubung dengan menggunakan email (Sitompul, 2001). 
Jika hanya dipertimbangkan secara logis berdasarkan cara lama, dipastikan dokumen elektronik tidak akan pernah terkonfirmasi dalam bentuk email. Ketika, dalam hal dominasi teknologi, Indonesia tidak kalah pada negara lainnya. Praktik bisnis di Indonesia sudah terlalu lama menggunakan alat komputer (Yuliana, 2000). Sejauh ini, semua pihak yang terlibat dalam transaksi (pertukaran informasi) tidak keberatan. Hingga saat itu, Indonesia seolah menjadi negara terbelakang dalam hal dominasi teknologi. Apabila pemerintah dan warga siap, perkara identifikasi dokumen elektro berupa email bukanlah hal baru pada praktik aturan Indonesia. Meskipun masih sangat sedikit masalah yg memakai indera bukti elektro menjadi indera bukti pada pengadilan (Rusmiatiningsih, 2017).

Dari pernyataan peneliti sebelumnya diketahui bahwa dalam hukum peradilan di Indonesia, pembuktian melalui email belum dianggap sah sebagai alat bukti yang berkekuatan hum penuh. Oleh karena itu, dalam penelitian ini melanjutkan penelitian sebelumnya yangmemfokuskan pada kajian bagaimana pembuktian penggunaan email berdasarkan Undang-undang ITE dan menelaah kekuatan email dalam proses persidangan apabila dikaitkan dengan pasal 1866 KUHPerdata

\section{METODE PENELITIAN}

Penelitian ini menggunakan penelitian hukum normatif dengan endekatan perundang-undangan dan kasus untuk melihat kekuatan hukum dari pembuktian alat bukti dalam persidangan (Marzuki, 2006). Sumber bahan hukum yaitu dokumen hukum yang diperoleh melalui studi pustaka atau arsip (Asikin \& Amiruddin, 2012). Dokumen hukum meliputi dokumen hukum primer, sekunder dan tersier. Dokumen hukum dasar, yaitu dokumen hukum yang diperoleh dari peraturan hukum. Bahan hukum sekunder adalah alat hukum dengan berikatan sangat kuat dengan suatu alat hukum primer dan berguna untuk analisis, pemahaman, dan interpretasi bahan hukum sekunder, meliputi: jurnal ilmu hukum, seminar media cetak dan elektronik. Bahan aturan taraf ketiga, yaitu bahan aturan yang bisa menaruh warta dan penerangan mengenai bahan aturan taraf pertama dan kedua. data dikumpulkan melalui teknik studi kepustakaan yaitu membaca dan menaganalisis bahan-bahan hukum, selanjutnya diolah secara kualitatif deskriptif

\section{HASIL DAN PEMBAHASAN}

\section{Pembuktian Penggunaan Email Berdasarkan Undang-undang ITE}

Berdasarkan Undang-undang Informasi dan Transaksi Elektronik Nomor 19 Tahun 2016, terdapat beberapa bahan yang disebut alat bukti lainnya di suatu pengadilan, yaitu dengan terkait pemberitahuan elektronik atau dokumen elektronik. Email adalah dokumen elektronik. Ketentuan umum UU ITE mengatur bahwa data elektronik seperti teks, foto, suara, dan gambar adalah informasi elektronik, sedangkan jenis informasi elektronik lainnya seperti teks, foto, suara, dan gambar disimpan. Perangkat komputer dapat membuka dokumen elektronik. Undang-undang tentang Dokumen Perusahaan No. 8 Tahun 1997 mengatur tentang konversi data teks menjadi data elektronik. Pada bagian yang membahas huruf $F$, dicatat bahwa "kemajuan teknis telah memungkinkan untuk lebih menekankan transfer catatan dan dokumen kertas. disebutkan dalam pasal 2 (1) dan pasal 15 (1), "Dokumen perusahaan dapat diubah menjadi mikrofilm atau media lain yang merupakan alat bukti yang sah.") UU 8/1997.

Dokumen elektronik dalam perusahaan, menjadi suatu alat bukti yang sah sebelum UU ITE dikeluarkan. Artikel ini secara berkhusus dengan menjelaskan tentang adanya arsip elektronik di peradilan perdata, agar tidak termasuk dalam UU Tindak Pidana Korupsi sebagai alat yang digunakan bukti indikatif dan dalam perkara pidana sebagai alat bukti lain dalam lingkup arsip elektronik. "UU Perlindungan Lingkungan" menetapkan. Dengan Ketentuan ayat 1 dan 2 Pasal 5 UU ITE secara jelas mengatur status menginformasikan elektronik atau simpan elektronik sebagai alat bukti yang relevan dan perluasan alat bukti yang menurut hukum acara yang berlakukan di Indonesia. Materi informasi elektronik file elektronik digunakan sebagai:alat bukti atas permintaan kepolisian, kejaksaan, dan lembaga penegak hukum lainya dalam menyambut penegakan hukum, seperti UU ITE (putusan MK) yang diatur dalam Pasal 31(1) 20/PUU XIV/2016). Menurut isi persidangan MK, putusan tersebut ditujukan pada prosedur peradilan pidana, bukan prosedur peradilan perdata.

Persyaratan hukum arsip elektronik adalah mempergunakan dengan suatu sistem elektronik yang sesuai sesuai dengan ketentuan UU ITE, khususnya UU ITE Pasal 6, yaitu "informasi 
elektronik dan/atau arsip elektronik dapat diakses sepanjang memuat informasi yang dianggap sah". , Tampilan dan Jaminan Penjelasan yang lengkap dan dapat ditafsirkan Selain itu, penggunaan otentikasi elektronik dan sistem elektronik untuk transaksi juga memiliki kekhasan. Surat Edaran Mahkamah Agung No. 14 Tahun 2010 tentang Dokumen Elektronik mengakui penggunaan pertama dokumen elektronik oleh Mahkamah Agung dalam sistem peradilan sebagai penetapan akhir permohonan pencabutan dan peninjauan kembali. Tujuan EMS adalah Meningkatkan efisiensi dan efektivitas proses pendaftaran, mendukung Melaksanakan transparansi dan akuntabilitas serta suatu pelayanan publikasi terkait Mahkamah Agung dan Peradilan. Namun, semua tidak memantau dokumen elektronik sebagai alat bukti, tetapi mencakup dokumen elektronik dalam bentuk sebagai berikut:permohonan banding dan review lengkap atas putusan atau surat dakwaan yang terdapat dalam CD, flash disk/dikirim melalui email. Pasal 137 HIR bahwa "suatu pihak yang terkait mendapatkan meminta untuk melihat sertifikat pihak lain, dan sebaliknya, dan surat pihak lain itu dikirimkan kepada hakim untuk itu". Dengan menjaga prinsip transparansi bukti pengadilan, ketika pihak lain meminta untuk menghasilkan dokumen elektronik, 137 peraturan HIR juga harus berlaku untuk dokumen elektronik. Oleh karena itu, diperlukan peralatan teknis berupa laptop atau proyektor untuk melihat/menampilkan dokumen elektronik, itupun tidak diatur.

\section{Kekuatan Email dalam Proses Persidangan Dikaitkan dengan Pasal 1866 Kuhperdata}

Tes sipil adalah untuk mendapatkan formalitas Waarheid. Kebenaran formal didasarkan pada bentuk hukum, sehingga teks yang benar ada cukup bukti dan kekuatan mengikat. Kesempurnaan dengan itu hakim tidak perlu alat bukti lain untuk memutus perkara selain alat bukti yang bersangkutan. Media pengikat bahwa kecuali dapat dibuktikan dengan cara lain, hakim harus menerima alat bukti yang nyata. Pasal 1866 KUH Perdata mengatur bahwa alat bukti meliputi alat bukti tertera tertulis, keterangan saksi, sangkaan, pengakuan, dan sumpah. Dalam hukum acara perdata, alat bukti yang disebut dalam bentuk surat merupakan alat bukti utama. Jika dikaitkan dengan HIR Pasal 164 tentang alat bukti yang sah, kekuatan bukti email digunakan sebagai proses persidangan, maka kekuatan email yang Cetakannya dianggap sama dengan surat aslinya dan memiliki kekuatan yang sama dengan keasliannya. Menetapkan syarat utama untuk dokumen elektronik sah adalah menggunakan sistem elektronik yang telah diverifikasi secara elektronik oleh pemerintah (Pasal 13 sd 16 UU ITE). Pasal 13 UU ITE menetapkan bahwa:

1) Setiap orang berhak menggunakan jasa penyelenggara sertifikat elektronik untuk melakukan tanda tangan elektronik

2) Penyelenggara sertifikat elektronik harus memastikan bahwa tautan sertifikat elektronik sertifikat dan tanda tangan pemilik

3) Penyelenggara Sertifikat Elektronik meliputi:

a) penyelenggara sertifikat elektronik Indonesia

b) penyelenggara sertifikat elektronik asing

4) penyelenggara sertifikat elektronik Indonesia yang terdaftar di Indonesia dan didirikan di Indonesia

5) penyelenggara sertifikat elektronik asing Penyelenggara sertifikat beroperasi di Indonesia Harus terdaftar di Indonesia,

6) Ketentuan lebih lanjut mengenai penyelenggara sertifikat elektronik sebagaimana dimaksud pada ayat (3) diatur lebih lanjut dengan peraturan pemerintah.

Pasal 14, penyelenggara otentikasi elektronik sebagaimana dimaksud dalam Pasal 13 (1) sampai dengan (5) harus memberikan setiap pengguna layanan informasi yang akurat, jelas dan tidak ambigu, sebagai berikut:

1) Metode yang Digunakan untuk mengidentifikasi penandatangan

2) Sesuatu yang dapat digunakan untuk mengetahui data pribadi pembuat tanda tangan elektronik

3) Sesuatu yang dapat digunakan untuk membuktikan keabsahan dan keamanan tanda tangan elektronik.

Menurut Pasal 15, ditetapkan:

1). Setiap penyelenggara sistem elektronik harus mengoperasikan sistem elektronik dengan andal dan aman dan bertanggung jawab atas pengoperasian sistem elektronik yang benar 
2). Penyelenggara sistem elektronik bertanggung jawab atas pengoperasian sistem elektronik anda

3). Apabila dapat dibuktikan bahwa pengguna sistem elektronik telah melakukan keadaan wajib, kesalahan atau kelalaian, maka ketentuan sebagaimana dimaksud pada ayat (2) tidak berlaku.

Menurut pasal 16:

1) Asalkan tidak ada undang-undang tersendiri yang mengatur lain, setiap penyelenggara sistem elektronik harus menyelenggarakan sistem elektronik yang memenuhi persyaratan minimal sebagai berikut:

a) Dapat menampilkan informasi elektronik

b) Dapat melindungi elektronik sistem ketersediaan, integritas, keaslian, kerahasiaan, dan aksesibilitas informasi elektronik dalam pengoperasiannya

c) Dapat digunakan sesuai dengan prosedur atau instruksi dalam pengoperasian sistem elektronik

d) dilengkapi dengan sistem sistem operasi elektronik yang dapat dipahami semua orang pihak yang berkepentingan Bahasa simbolis, informasi atau prosedur pengumuman atau deskripsi

e) Ada mekanisme yang berkelanjutan untuk menjaga kebaruan, kejelasan dan integritas prosedur atau deskripsi,

Persyaratan lain adalah untuk menempatkan tanda tangan elektronik, memasukkannya ke dalam kontrak elektronik standar, dll. Oleh karena itu, status berkas elektronik tersebut ini sebenarnya merupakan perpanjangan dari alat bukti yang dijelaskan dalam Pasal 1866 BW. Nilai pembuktian dari dokumen tertulis yang diatur dalam UU Bukti Perdata sangat tergantung pada bentuk dan tujuan dari dokumen tersebut. Ketika file elektronik disertifikasi oleh otoritas dan memperkenankan persyaratan, cerita bisa disebut kesepakatan yang tepat seumpama kesepakatan elektronik yang sah.

\section{SIMPULAN DAN SARAN}

\section{Simpulan}

Berdasarkan hasil dan pembahasan di atas, dapat disimpulkan bahwa alat bukti email berupa email digunakan di pengadilan. Secara jelas dalam UU ITE menyatakan berlaku, jenis alat bukti ditambahkan dan berkas elektronik diakui sebagai bahan bukti yang kuat. Kekuatan pembuktian melalui email dipergunakan sebagai alat pembuktian di persidangan. Jika dikaitkan dengan pembuktian yang sah dalam HIR pasal 164, kekuatan email saat dicetak dianggap serupa pakai piagam aslinya dan mempunyai harkat yang serupa pakai aslinya. Syarat asas suatu dokumen elektronik bisa dinyatakan serupa perlengkapan kenyataan yang original adalah mengabdikan susunan elektronik yang taksiran verifikasi secara elektronik oleh pemerintah (pasal 13 sd $16 \mathrm{UU}$ ITE).Syarat lainnya adalah tanda tangan elektronik, membutuhkannya pada kontrak elektronik standar. Jika dokumen elektronik disertifikasi oleh pemerintah dan memenuhi persyaratan, maka dapat disebut kontrak yang benar sebagai kontrak elektronik yang sah.

\section{Saran}

Berdasarkan simpulan di atas, adapun saran yang disampaikan peneliti yaitu bagi pemerintah dan amtenar peletak hukum, terlazim mencerna pentingnya amanat pengesahan teruit pakai peredaran rekayasa dokumen elektronik dalam bentuk email, dan mengedukasi masyarakat tentang penggunaan email sebagai sumber informasi. Setelah Undang-undang ITE berlaku, masyarakat perlu memahami agar mereka memiliki juga pertimbangkan nilai pembuktian alat bukti elektronik. Bagi pelaku kejahatan, perlu dipahami penggunaan email sebagai alat bukti bagi siapa saja yang menggunakan fasilitas komputer untuk melakukan kejahatan dengan mempertimbangkan akibat dari perbuatannya.

\section{DAFTAR PUSTAKA}

Anggara. (2010). Kontroversi UU ITE: Menggugat Pencemaran Nama Baik di Dunia Maya. PT.Penebar Swadaya: Jakarta.

Asikin, Z., \& Amiruddin. (2012). Pengantar Metode Penelitian Hukum. Raja Grafindo Persada: Jakarta.

Fathurrahman, M. (2018). Pentingnya Arsip Sebagai Sumber Informasi. JIPI (Jurnal Ilmu Perpustakaan Dan Informasi), 3(2), 215-225.

Hamzah, A. (2014). Hukum Acara Pidana Indonesia. Jakarta: Sinar Grafika.

Marzuki, P. M. (2006). Penelitian Hukum. Kencana: Jakarta. 
Mertokusumo, S. (1998). Hukum Acara Perdata Indonesia. Raja Grafindo: Bandung.

Prodjodikoro, W. (2003). Tindak-Tindak Pidana Tertentu. Refika Aditama.

Rusmiatiningsih. (2017). Legalisasi Arsip Elektronik Sebagai Alat Bukti Hukum. Jurnal Kearsipan, 12(1), 101-113.

Saleh, R. (2007). Spam dan Hijacking Email. Andi Offset: Yogyakarta.

Sitompul, A. (2001). Hukum Internet (Pengenalan Mengenai Masalah Hukum di Cyberspace). PT. Citra Aditya Bakti: Bandung.

Subekti, R. (1989). Hukum Acara Perdata. Binacipta: Bandung.

Tutik, T. T. (2006). Pengantar Hukum Perdata di Indonesia. Prestasi Pustaka Publiser.

Yuliana, O. Y. (2000). Penggunaan Teknologi Internet dalam Bisnis. Jurnal Akuntansi Dan Keuangan, 2(1), 36-52.

Zazili, A. (2012). Pengakuan Negara Terhadap Hak-hak Politik Masyarakat Adat dalam Pelaksanaan PEemilihan Umum (Studi Putusan Mahkamah Konstitusi No.47-81/PHPU.A-VII/2009). Jurnal Konstitusi, 9(1), 108446. 